\title{
ASO Author Reflections: How to Identify Patients at Genuinely High Risk of Recurrence from Localized Gastrointestinal Stromal Tumor of the Stomach?
}

\author{
Toto Hølmebakk, $\mathrm{MD}^{\mathbf{1}}$, and Kjetil Boye, $\mathrm{MD}, \mathrm{PhD}^{2,3}$ \\ ${ }^{1}$ Department of Abdominal and Pediatric Surgery, Oslo University Hospital, The Norwegian Radium Hospital, Oslo, \\ Norway; ${ }^{2}$ Department of Oncology, Oslo University Hospital, The Norwegian Radium Hospital, Oslo, Norway; \\ ${ }^{3}$ Department of Tumor Biology, Institute for Cancer Research, Oslo University Hospital, The Norwegian Radium Hospital, \\ Oslo, Norway
}

\section{PAST}

The overall survival benefit of adjuvant imatinib for localized GIST is uncertain, ${ }^{1,2}$ and clinicians generally maintain that the risk of recurrence should approach 50\% for 3 years of treatment to be justified. For gastric GIST, the risk is low, and even in the high-risk category, recurrence-free survival exceeded $75 \%$ in one large study that administered adjuvant treatment only to a minority. ${ }^{3}$ Risk stratification is obscured by the increasing use of neoadjuvant treatment, which precludes assessment of mitotic activity. Other variables would be valuable, and there are indications that anatomical features are associated with outcomes. ${ }^{4}$ Population-based data specifically on patients with gastric GIST are lacking.

\section{PRESENT}

In this study, few recurrences were detected among patients with luminal or exophytic tumors, and without rupture, their prognosis was excellent irrespective of tumor size. ${ }^{5}$ These patients may not benefit from adjuvant imatinib. By contrast, a transmural growth pattern was a predictor of poor outcome and associated with increased mitotic activity. After neoadjuvant treatment, when the

(C) The Author(s) 2021, corrected publication 2021

First Received: 16 November 2020

Accepted: 18 November 2020;

Published Online: 9 March 2021

T. Hølmebakk, MD

e-mail: tothol@ous-hf.no mitotic index is unknown, the growth pattern could serve as a surrogate variable, with continued imatinib treatment reserved for patients with transmural tumors. Tumor genotypes had a characteristic anatomical distribution: platelet-derived growth factor receptor- $\alpha$ (PDGFRA)-mutated tumors were situated in the lower end of the stomach and KIT-mutated tumors in the upper end, where tumors with deletions involving codons 557 and 558 in KIT exon 11 were concentrated in the upper third. The incidence of KIT/PDGFRA wild-type tumors was only $4 \%$. More than $90 \%$ of the tumors in the upper third harbored mutations associated with imatinib sensitivity. For patients with tumors in this location, when facilities for molecular testing are unavailable, the authors suggest that neoadjuvant treatment could nevertheless be started and that even adjuvant treatment could be considered.

\section{FUTURE}

The authors have documented associations between anatomical, molecular, and clinical characteristics of gastric GIST. These findings could stimulate studies to identify the underlying biologic processes that explain the multifarious nature of this disease together with their potential as biomarkers for therapeutic decisions. In oncology, there is an innate drive to expand therapy in the hope of curing or deferring disease. Equally important should be the restriction of therapy when benefit is unlikely. For patients with gastric GIST, further efforts should be made to identify those who could be spared the side effects, costs, and inconvenience of extensive adjuvant treatment. 
FUNDING Open access funding provided by University of Oslo (incl. Oslo University Hospital).

DISCLOSURE There are no conflicts of interest.

OPEN ACCESS This article is licensed under a Creative Commons Attribution 4.0 International License, which permits use, sharing, adaptation, distribution and reproduction in any medium or format, as long as you give appropriate credit to the original author(s) and the source, provide a link to the Creative Commons licence, and indicate if changes were made. The images or other third party material in this article are included in the article's Creative Commons licence, unless indicated otherwise in a credit line to the material. If material is not included in the article's Creative Commons licence and your intended use is not permitted by statutory regulation or exceeds the permitted use, you will need to obtain permission directly from the copyright holder. To view a copy of this licence, visit http://creativecommons. org/licenses/by/4.0/.

\section{REFERENCES}

1. Casali PG, Le Cesne A, Velasco AP, et al. Time to definitive failure to the first tyrosine kinase inhibitor in localized GI stromal tumors treated with imatinib as an adjuvant: a European Organisation for Research and Treatment of Cancer Soft Tissue and Bone Sarcoma Group Intergroup randomized trial in collaboration with the Australasian Gastro-Intestinal Trials Group, UNICANCER, French Sarcoma Group, Italian Sarcoma Group, and Spanish Group for Research on Sarcomas. J Clin Oncol. 2015;33:4276-83.

2. Joensuu H, Eriksson M, Sundby Hall K, et al. Survival outcomes associated with 3 years vs 1 year of adjuvant imatinib for patients with high-risk gastrointestinal stromal tumors: an analysis of a randomized clinical trial after 10-year follow-up. JAMA Oncol. 2020;6:1241-6.

3. Kim M-C, Yook J-H, Yang H-K, et al. Long-term surgical outcome of 1057 gastric GISTs according to 7th UICC/AJCC TNM System. Medicine. 2015;94:e1526-7.

4. Miettinen M, Lasota J. Gastrointestinal stromal tumors: pathology and prognosis at different sites. Semin Diagn Pathol. 2006;23:70-83.

5. Hølmebakk T, Wiedswang AM, Meza-Zepeda LA, et al. Integrating anatomical, molecular and clinical risk factors in gastrointestinal stromal tumor of the stomach. Ann Surg Oncol. 2021. https://doi.org/10.1245/s10434-021-09605-8.

Publisher's Note Springer Nature remains neutral with regard to jurisdictional claims in published maps and institutional affiliations. 